\title{
Evaluation of the Implementation of the Universal Basic Education Yoruba Language Curriculum in South Western Nigeria
}

\author{
AYODELE Christiana Ayo \\ Department of Arts and Language Education, Ekiti State University, Ado Ekiti, Nigeria \\ OYINLOYE Gabriel Oludele \\ Department of Arts and Language Education, Ekiti State University, Ado Ekiti, Nigeria
}

\begin{abstract}
The study evaluated the implementation of the Universal Basic Education Yoruba Language Curriculum in South Western States of Nigeria. The purpose is to determine the extent of the coverage of the Curriculum. It is also meant to determine whether the objectives of the Yoruba Language Curriculum are achieved. Also, it is meant to ascertain the attitude of the students towards the learning of Yoruba Language. The study is a descriptive research of the survey design. The population consists of all students and teachers that are teaching Yoruba Language in all upper Basic Schools in South Western Nigeria. A sample of 1500 respondents which consists of 1200 students and 300 teachers that are teaching Yoruba Language in upper Basic Schools was selected through the use of multistage sampling techniques. Three (3) Research questions and (2) Two Hypotheses were used and tested at 0.5 level of significance. Four instruments were used to elicit information. They are, Teachers' Questionnaire on implementation of the Universal Basic Education Yoruba Language Curriculum, Questionnaire on students' attitude towards learning of Yoruba language and Students achievement test. The students' class notes were also used to know the extent of the work done. The data generated were subjected to descriptive analysis and inferential statistics. The findings revealed that, there was a low positive relationship between the Universal Basic Education Yoruba Language Curriculum and its implementation.
\end{abstract}

Index Terms - evaluation, implementation, Universal basic education, curriculum, Yoruba language

\section{INTRODUCTORY DISCOURSE}

The fortune of any country depends on the extent of the enlightenment of the citizen and their ability to contribute meaningfully to the development of such country. Education has been recognized as a process of imparting knowledge, skills and attitude with the purpose of ensuring total development of the children. Danmole (2011) explained that education has remained an instrument of change and national development. It is a process of transmitting, refining and preserving the collective values embedded in the society (Oyekan, 2005).

Education is a systematic process through which an individual is introduced to all sphere of life that exist in society such as economic, social, moral, politics, intellectual and a set of behaviour, attitude and values. Investment in human capital has over the years been recognized to be the bedrock of increased productivity and hence economic development (Ayodele, 2005). Education is the utmost tool which an individual needs in order to acquire knowledge and personal experience with which to live comfortably and make a meaningful contribution to the advancement of the community and the nation at large. Thus education can be recognized as a process by which a society reproduces itself by passing on its main characteristics, values and culture to the next generation and keep on improving its quality and modes of life. It is supposed to result in changing the behaviour of the individual for self-realisation and sustainable development.

The aims of education is to equip an individual with knowledge which will assist him or her in the attainment of broad mind, critical thinking, social and individual fulfilment in life. Its purpose is the development of the intelligence in such a way that the experience one gets at one time can be carried over to a subsequent experience and used in solving one's life problem. (Yaaka, 2019). Nigerians attached a considerable importance to the education of their children. The indigenous education in Nigeria emphasised practical arts, health and sanitation, farming, fishing, trading, folktales, buying and selling - entrepreneurship skills, rituals and after knowledge that are related to day to day living in a bid to engage the children in functional education. The antecedent of western education in Nigeria was dated to the missionary days prior to the independence. Education was introduced towards inculcation of norms, value, skills and attitudes inherent in cultural heritage but the system of education was not guided by any uniform policy and of course not coordinated. Umar (2006) stressed that the Nigeria education system then was on academic or cognitive components instead of vocational or technical skills and that there was dearth of highly skilled manpower in agriculture, aviation, engineering, medicine and other specialised area of human endeavour. In the quest for a universal access to education for its citizen, Nigeria has made several efforts through the establishment of some policies such as the introduction of 
the Universal Primary Education in 1976 which was short lived. The essence was to assist the country to overcome the challenges facing education and curb mass illiteracy by making sure that all children of primary school age were enrolled. It was also tailored towards the development of the Nigeria child but there was a rapid increase in enrolment and no emphasis on the itemised objective. The program did not achieve the desire goals.

In the quest for a universal and free education, the Universal Basic Education was inaugurated in 1999 to address the problem of access, quality and equity in Nigerian Education system and the total eradication of illiteracy and poverty among present and future generation. It was also in line with universal declaration and Education for All held in Jomiten (1991) of which Nigeria was a signatory. Specifically, the program was meant to enable the citizen to have access to quality education in order to broaden and widen the educational opportunities for all in a bid to eradicate illiteracy, ignorance and poverty among the citizen. Oduolowu (2007) noted that Nigerians Educational Statistics of 1996 showed that only 14.1 million children enrolled in primary schools out of about 21 million children of school age. Apart from this, Oluwatayo (2009), equally noted that the major purpose of the Universal Basic Education is to assist in the development of Nigeria culture, separate from the culture of different nationalities that make up the nation. Basic Education in actual sense can be referred to as all tiers of organised education and training that meets the basic learning needs of learners including literacy, numeracy, general knowledge, skills acquisition and all attitude required for the learners to survive and develop accountability, live and work in dignity. Based on this, the Universal Basic Education accentuated the prominence of language of immediate community, this was in response to the agitation of the people for the teaching of indigenous languages in schools in order to protect, preserve and promote the culture of Nigerians and for the fear of the indigenous language going into extinction. This was also to support the recommendations of the National policy on Education which emphasised that Government appreciate the importance of language as a means of promoting interaction and National cohesion and preservation of culture which further stressed that every child shall learn the language of his/her immediate environment in the interest of national unity (Federal Government of Nigeria 2004). Thus Hausa, Igbo and Yoruba languages were introduced among core subjects in the UBE programme.

\section{Yoruba LANGUAGe CURRICULUM}

Yoruba language is a language originally spoken by the Yoruba tribe of western part of Nigeria even though the language has spread widely across the nation to international countries. A tribe that has existed for centuries before 1819 (Awoniyi, 2006). Generally the aim of acquiring education in Yoruba traditional system is for the individual to become an Omoluabi that is to develop his personality and character and weave him harmoniously into the school pattern (Awoniyi, 2006). In line with this Fafunwa (2004) view that the aim of teaching Yoruba language is to allow the students to communicate orally and literally in the language. It is also meant to inculcate the Yoruba morals and values into the younger generation and to develop the child physical skill and character. All these are embedded in the 9-year UBE Yoruba language curriculum.

The 9-year UBE Yoruba language curriculum spelt out the objectives as follows

$>\quad$ that the students should be able to develop ability to think critically, read properly, write adequately, speak fluently in Yoruba language.

$>\quad$ to acquire adequate knowledge on the use of Yoruba language putting into consideration the rules guiding the use of speaking and writing of the language.

$>\quad$ to imbibe the culture and tradition in their daily activities.

$>\quad$ to acquire knowledge and development of entrepreneurship skills as practised among the Yoruba people and adequate preparation for secondary school education (NERDC).

In view of this, a curriculum was designed to serve as roadmap which spelt out the contents which the students must complete together with the teachers' input that will assist the teachers to make proper delivery of the lessons towards attaining the academic performance. The curriculum is meant to be a tool to facilitate effective learning. Seweje (2004) presented the curriculum as a plan of the teaching and learning activities involving both the teacher and his pupils adding that curriculum includes all planed programmes of activities that are geared towards the development of the learner physically and spiritually within an education setting with a view of developing the society's culture. In September 2008, the UBE programme was changed to 9 years continuous programme because it was observed that, Nigeria system of education suffers a serious setback in the acquisition of skills, critical thinking and the use of intelligence coupled with good ideas to approach issues for meaningful living to be able to face the challenges in the society. It was also observed that the use of mother tongue is very important to knowledge acquisition.

The Yoruba language curriculum was expanded and modified to lay more emphasis on the acquisition of skills in cognitive, affective and psychomotor domains of learning. More importantly it was modified to accommodate the teaching of intellectual, ethical and moral responsibilities, entrepreneurial skills and ability of the students to build up social acceptance behaviour, treasure and preservation of Yoruba culture. The contents of the curriculum is characterised by the teaching of grammar, culture and oral and written literature. Ajibola (2008) emphasised that the Yoruba language curriculum involved the infusion of indigenous knowledge and technologies such as traditional arts and crafts, traditional food system and medicine, knowledge of the environment and African civilisation, communication skills which is the ability to read Yoruba language text with understanding. NERDC (2008) emphasised that, no topic or aspect of teaching, learning process should be left to chance therefore Teachers should practice the 
skills that pose challenges to them very well before they go into the classroom to teach. All these are specified and broken down into learnable units and topics. They are also organised and structured into various sections with specified instructional objectives which the students are to achieve at the end of a particular lesson for easy teaching and learning to take place. Obiama (2008) noted that, learners having successfully passed through nine years basic education should have basic rudiment for creative thinking, high moral and ethical values.

Therefore, in order to appreciate the values of this curriculum, it needs to be implemented accordingly - as a way of getting the plan working. It is the duty of the teachers to interpret the curriculum into a workable blueprint. Eamon Stack (2005) opined that the task of curriculum implementation is complex that involves teachers translating curriculum document into practice, embracing new teaching programmes, and methodologies and providing a broader range of learning experiences for their pupils. The extent to which a curriculum is implemented in the classroom could be associated with the teacher's involvement in the process. Kelly (2018) explained that, teachers hold the key to the curriculum process adding that using a wide variety of techniques, teachers encourage learning by delivering contents in creative and impactful ways. The successful implementation of the Universal Basic Education Yoruba Language curriculum will facilitate effects to reduce illiteracy to the minimum and increase the productive workforce in all the sectors of the economy. Oyekan (2005) stressed that the creative self - relevant UBE graduates shall not be easy preys of ignorance, violence, political enslavement and economic exploitation as they would engage in production of sustainable wealth and efficient service to live descent gainful life. Therefore, in order to implement the curriculum effectively, there must be a flow of knowledge from the teacher to the students. This can be carried out through

$\checkmark \quad$ Effective selection of contents

$\checkmark \quad$ Proper planning of instructional activities and learning experiences

$\checkmark \quad$ Adequate utilisation of instructional materials

$\checkmark \quad$ Proper selection of learning environment

$\checkmark$ Application of what the learners have learnt to new situation and the desire to continue in learning.

\section{- Selection of Contents.}

The contents of the curriculum contains activities which if adequately executed would develop students intelligence and personality to a reasonable extent. Seweje (2004) noted that attention to the selection of contents is always an important aspect in curriculum consideration. The UBE Yoruba language curriculum contents have been selected, broken down into units and topics and spread across the classes involved to toll the line of facilitating efforts to reduce illiteracy to the minimum and increase the productive workforce in all the sectors of the economy. Oyekan (2005) stressed that the creative self-reliant UBE graduate shall not be easy prey of ignorance, violence, political enslavement and economic exploitation as they would engage in production of sustainable wealth and efficient service to live decent gainful life. Ofoha, Uchegbu, Anyikwa and Nkemdirin (2009) viewed that the curriculum is appropriate in terms of goals and contents. The teachers need to study the document for proper implementation.

\section{- Planning of instructional activities and learning experience.}

Meader (2018) noted that preparation and planning are critical components of effective teaching. The teachers' preparation must always be in line with the stated objectives in planning instructional activities, one of the essential tool is the lesson plan. The lesson plan is the detailed explanation of the process of instruction which the teacher intended to give the learners. It helps the teacher and the learner to achieve a virile learning objective. Teachers are expected to determine the topic of the lesson from where to generate the lesson objective. They are to organise the contents and make procedure for a successful lesson.

The learning experience is the interaction between the teacher, the learners and the learning environment. This is the experience that the learners have during the course of instruction. It is the duty of a professional teacher to engage teaching in a gradual process. This will enable the learners to have close interaction with the contents for learning to take place in order to achieve the instructional objective. It is highly essential for the teachers to teach the contents sequentially. He is expected to guide the learners through the difficulties encounter in the process of learning.

\section{- Adequate utilisation of instructional materials.}

Instructional materials are resources that can be used to facilitate learning. Adeniyi (2010) refers to instructional materials as materials used by teachers in enhancing the process of teaching and helping the learners to grasp what he intends to communicate to them clearly. The consistent use of learning resources can provide first-hand information and hold students attention which will invariably lead to meaningful understanding of the contents and enhance permanent learning.

\section{- Learning outcome.}

This is the extent at which the students exhibit the desired learning needs. It is to be determined by the teacher through assessment which may be by grading or other means. There must be evidence of students' application of what they have learnt to new situation and the desire to continue learning. It is the belief of the curriculum developers that what the learners have learnt in the upper basic will lay the foundation for the desire to continue learning Yoruba language.

However, the researcher observed that the overall knowledge of the graduate of the Basic Education in Yoruba language at the end of their Basic circle of Education is not encouraging. It seems the graduate of Basic Education Yoruba language are not morally, attitudinally and culturally influenced by the curriculum. It appears many of them still 
lack basic lifelong skills and they are not functionally literate in the language. It appears the amount of contents being exposed to in Yoruba language has not met the aspiration of the nation to make them to be self-reliant. Thus Osalusi (2011) noted that none of the educational needs of the child has been implemented on a really significant scale.

Obanya (2004) equally noted that there seems to be a mismatch between what is prescribed, what is practised and what is achieved by the curriculum. It seems the appropriate corresponding learning experience to the objectives as earmarked by the curriculum have not been achieved hence a lot of students failed to continue further learning the subject at the higher level. The objectives of the UBE Yoruba language cannot be achieved if the curriculum is not well implemented. It is on this note that this research evaluate the implementation of the Universal Basic Education Yoruba Language Curriculum.

\section{THEORETICAL FRAMEWORK}

The theoretical model for this study is based on Context, Input, Process, Product (CIPP) curriculum evaluation model of Stufflebeam (1971) which is a decision oriented model. It is a model that involves the use of judgement on the extent of the attainment of stated goal. This mode has its route from Tyler (1949) evaluation model. Tyler stressed that, evaluation as process seeks to determine the extent at which the educational objectives of educational programme or a curriculum are actually being attained. Tyler in his view stressed that, the achievement of outcome is very essential and paramount in accordance with the stated goals and objectives in which outcome should be related to the stated goals to determine if there is any discrepancy which could lead to judgement. The CIPP identifies four types of evaluation which are - context evaluation, input evaluation, process evaluation and product evaluation. It can as well explain what needs to be done, how it should be, is it being done? And did it succeed? The main purpose of the theory is to make decision on an educational programme in order to determine the extent of which the objectives have been realised. This is with a view whether to improve on the programme, to terminate it or to proceed. The content is the reason, the basis for the programme. It diagnoses the problems and describes the programme objectives. It compares the actual with the intended. It is a way of setting a particular goal to be achieved using the content of the curriculum.

The second stage is input. The inputs are the resources to be used which can bring about achievement of the desired goals. This encompasses the available resources that are provided in order to be sure that objectives are effectively attained. It means using various facilities and methods of teaching to interact with the students.

The next stage is process. This is the interaction of the teachers, the learners and the materials in the classroom. The process is the actual classroom situation where the curriculum is put into operation. It involves assessing to discover various problems that may come up in the course of the programme.

The next is product. Product is the achievement or the output of the programme. This will also determine the quality of the contents of the curriculum in transforming the learners.

The justification for the use of the model is that, it is a comprehensive framework for guiding evaluation programmes, personnel, projects, products, institutions and system. It is to evaluate the effectiveness of a programme to know the extent of achieving the stated objectives. It will also assist in determining the unmet needs, assess the products and take decision to be able to provide feedback for corrective purpose.

The adapted model for this evaluation study can be summarised in the following diagram

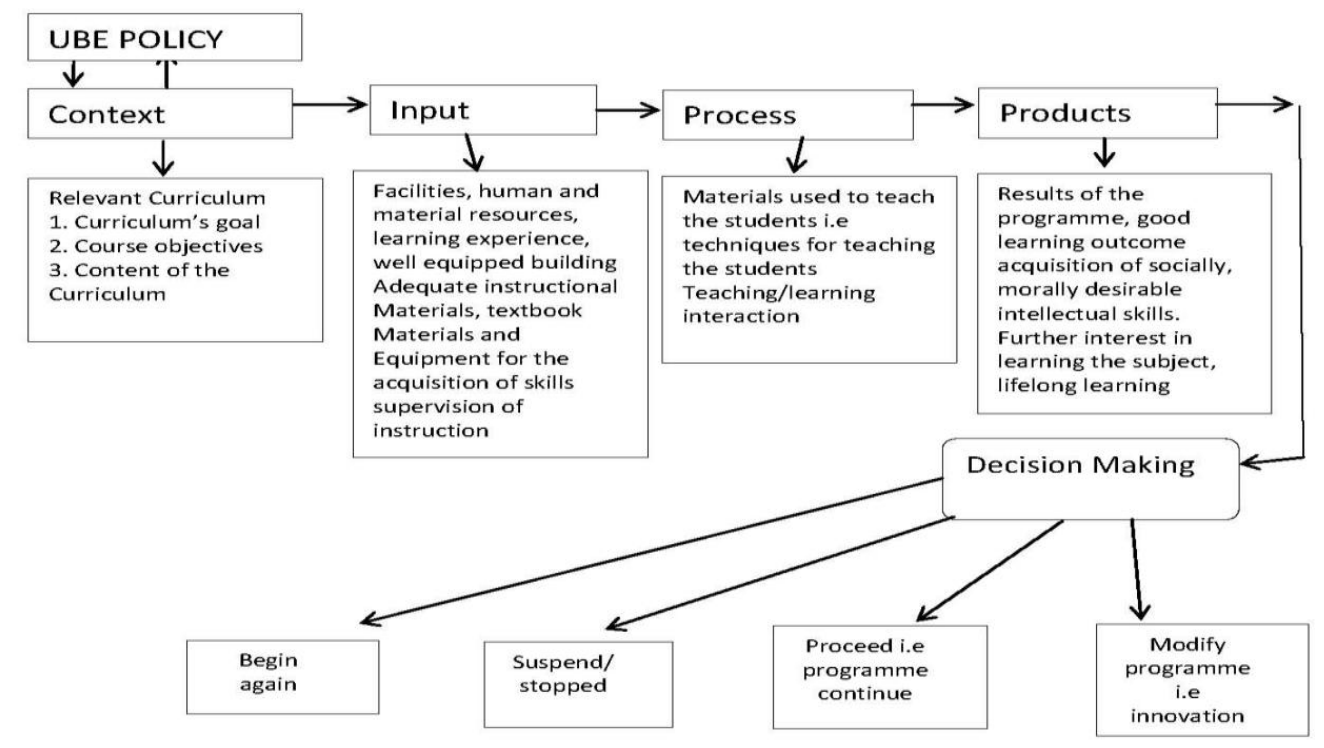

Context: the context represents the goals and objectives, provisions of Universal Basic Education Yoruba Language Curriculum as well as the contents of the Curriculum. This is in accordance with the context of the Curriculum in terms of Curriculum goals, course objectives contents of the Curriculum, the context as recommended by the UBE Yorùbá 
Language Curriculum are for the students to be able to acquire critical thinking, read properly, write adequately and speak fluently in Yorùbá Language to acquire adequate knowledge on the use of Yorùbá Language, putting into consideration the rules guiding the use of speaking and writing of Yorùbá Language. To imbibe the culture and tradition in his daily activities, to enable the students to speak Yorùbá Language fluently without mix up, to develop interest at reading Yorùbá Newspaper, journals and story books, to acquire knowledge in writing stories, to develop interest in the acquisition of traditional Yorùbá skills and vocations, adequate preparation for senior secondary school education.

Input: The inputs represent the facilities, that is, human and material resources. The UBE promise to make provision for human and material resources, facilities. (NERD, 2008). Hence, the inputs in the model represent the facilities and material resources to implement the Yorùbá Language Curriculum as well as the learning experiences of the learners and other environmental conditions.

Process: The process is the interaction of the learners with learning environment and the learning facilities through the effort of the teachers. It represent the process of implementing the programme, material used to teach the students, teaching strategies, techniques for teaching the students.

Product: These are the actual behaviour exhibit by the learners, as a result of being exposed to the course.

It represent the outcome, that is, the expected behaviour, good learning outcome, successful academic achievement, acquisition of socially, morally desirable intellectual skills. Further interest in learning the subject, lifelong learning. Source: UBE Yorùbá Language Curriculum (NERD, 2008).

The system operation represents the UBE programme itself, there is an arrow that shows the linkage between the UBE system operation and the context. Also another arrow shows the interconnectivity between the context to the input and the process, finally link with the product. After the product, the decision will be taken on the programme either to suspend the Curriculum, if it is not beneficial to the learner or to proceed on the programme, if the programme is relevant and of good benefit to the students or to modify it and modification could come in terms of innovation.

\section{Statement of the Problem}

The researcher observed that the performance of the Yoruba language students at the end of their basic circle of education is not encouraging. It is observed that the corresponding appropriate educational experience to the objectives of the UBE Yoruba language curriculum has not been achieved. Also the practicality of the language to teach cultural and traditional occupation is gradually fading away and the rate at which students drop out in Yoruba language kept on increasing. In view of these problems, the evaluation of the Yoruba language UBE programme becomes very germane.

\section{RESEARCH QUESTIONS}

1. Are the copies of Universal Basic Education Yoruba language curriculum available in schools for teachers teaching Yoruba language to use?

2. Are the contents of the curriculum fully implemented by teachers teaching Yoruba language?

3. What is the outcome of the student's performance in the achievement test?

\section{PURPOSE OF THE STUDY}

The purpose of this study is to evaluate the implementation of the universal Basic Education Yoruba language curriculum in public secondary schools in South Western States of Nigeria. This is to ascertain the extent of the coverage of the Curriculum. The study also seek to determine how the objectives of the UBE Yoruba language Curriculum being achieved.

\section{METhODOLOGY}

The study adopted a descriptive research of the survey type. The population consisted of all Yoruba language teachers and students in the upper basic public schools in the South Western States of Nigeria. The sample consisted of 300 teachers that are teaching Yoruba language and 1,200 students of Yoruba language in the upper basic schools.

Three instruments were used to elicit information from the respondents. The teachers' questionnaire on the implementation of the Universal Basic Education Yoruba language curriculum, with the reliability of 0.78, secondly, the questionnaire on students' attitudes towards the implementation of the UBE Yoruba language curriculum with the reliability coefficient of 0.76 and the students' achievement test on the implementation of the UBE Yoruba language curriculum.

\section{RESEARCH HYPOTHESES}

The following hypotheses were generated to guide this study.

Hypothesis 1

There is no significant relationship between the prescribed contents of the UBE Yorùbá Language Curriculum and its implementation.

Hypothesis 2 
There is no significant relationship between students' attitude and acquisition of Yoruba language skills, cultural values and the development of entrepreneurship skills in the implementation of UBE Yoruba language Curriculum.

Results

Question 1 - Are the copies of the Universal Basic Education Yoruba language Curriculum available for the teachers teaching Yoruba language?

TABLE 1

FREQUENCY COUNTS AND PERCENTAGE OF RESPONSES ON AVAILABILITy OF UBE YORUBA LANGUAGE CURRICULUM

\begin{tabular}{|c|c|c|c|c|}
\hline \multirow[t]{2}{*}{ Items } & \multicolumn{2}{|c|}{ Agree } & \multicolumn{2}{|c|}{ Disagree } \\
\hline & Freq & $\%$ & Freq & $\%$ \\
\hline $\begin{array}{l}\text { Every Yoruba language teacher has a copy of the UBE Yoruba language } \\
\text { curriculum in your school? }\end{array}$ & 28 & 9.3 & 272 & 90.7 \\
\hline Copies of Yoruba language UBE curriculum are not available in schools & 240 & 80.0 & 60 & 20.0 \\
\hline $\begin{array}{l}\text { Teachers copy the previous year's scheme of work to teach due to non- } \\
\text { availability of curriculum in schools }\end{array}$ & 261 & 87.0 & 39 & 13.0 \\
\hline
\end{tabular}

Table 1 shows that only $28(9.3 \%)$ of the teachers has copies each of UBE Yoruba language curriculum while 272 that is $(90.7 \%)$ did not have. On the other hand, $240(80 \%)$ of the teachers indicated non availability of copies of Yoruba language curriculum while 39 (13\%) disagreed on this. However, 261 which is $(87 \%)$ of the teachers use to copy previous year's scheme work to teach due to non-availability of the UBE curriculum while 39 that is $39 \%$ disagreed on this.

Question 2 - Are the contents of the Curriculum fully implemented?

TABLE 2

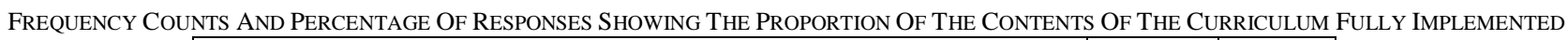

\begin{tabular}{|l|l|l|}
\hline Level of implementation of UBE Yoruba language curriculum & Freq & $\%$ \\
\hline Low $0.00-59.00$ & 217 & 72.3 \\
\hline High $60.00-100$ & 83 & 27.7 \\
\hline Total & 300 & 100 \\
\hline
\end{tabular}

Table 2 showed that 217 which is $(72.3 \%)$ of teachers indicated low level of implementation of the UBE Yoruba language Curriculum while 83 that is $(27.7 \%)$ of teachers indicated high level of implementation of the Curriculum.

In addition to this, students Yoruba language class notebooks which comprised the workload of JSS 1-3 were compared with the record of work done. The result is presented in table 3.

TABLE 3

Percentage Score Of The Level Of The Contents Of The Yoruba Language CurRiculum BeING IMPLEMENTED

\begin{tabular}{|c|c|c|c|c|}
\hline Class & JSS1 & JSS2 & JSS3 & Total Average \\
\hline$\%$ of coverage of the curriculum & 35 & 28 & 30 & 27.66 \\
\hline
\end{tabular}

From the table 3 , it was discovered that $27.66 \%$ of the whole curriculum contents were covered at the end of the basic circle of education.

Therefore the implementation of the UBE Yoruba language contents is very low. This implies that the contents of the curriculum have not been fully implemented.

Question 3 - What is the outcome of the students' performance in achievement test?

TABLE 4

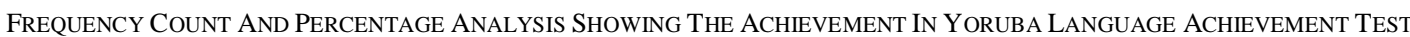

\begin{tabular}{|l|l|l|l|l|}
\hline Score & Grade & Freq & Percentage & Remark \\
\hline 70 above & A & 54 & 4.5 & Excellent \\
\hline $60-69$ & B & 62 & 5.1 & Good \\
\hline $50-59$ & C & 120 & 10 & Average \\
\hline $40-49$ & D & 253 & 21.1 & Fair \\
\hline $1-39$ & E & 711 & 59.3 & Poor \\
\hline Total & - & 1200 & 100 & \\
\hline
\end{tabular}

Table 4 showed that 54 which is $(4.5 \%)$ of the students examined scored 70 and above which is excellent while 62 $(5.1 \%)$ of the students examined scored $60-69$ marks which is good. It is further revealed that 120 that is $(10 \%)$ of the students examined scored $50-59$ marks which is average. Also 253 that is $(21 \%)$ of the students examined scored $40-$ 
49 which is fair while 711 that is $(59.3 \%)$ of the students examined scored $1-39$ marks which is poor. This indicated that the performance of the students by the results of the achievement test is very poor. This implies that, the implementation has not been fully achieved.

\section{Testing of Hypotheses}

\section{Hypothesis 1}

There is no significant relationship between the prescribed contents of the UBE Yorùbá Language Curriculum and its implementation.

TABLE 5

PEARSON PRODUCT MOMENT CORRELATION OF ANALYSIS OF PRESCRIBED CONTENTS OF UBE YORUBA LANGUAGE CURRICULUM AND ITS IMPLEMENTATION

\begin{tabular}{|l|l|l|l|l|l|}
\hline Variables & N & Mean & SD & r cal & r tab \\
\hline $\begin{array}{l}\text { Prescribed contents of UBE Yoruba } \\
\text { Language Curriculum }\end{array}$ & 300 & 152.60 & 24.54 & 0.464 & 0.195 \\
\hline $\begin{array}{l}\text { Implementation of UBE Yoruba } \\
\text { Language Curriculum }\end{array}$ & 300 & 58.01 & 10.33 & & \\
\hline
\end{tabular}

Table 5 shows that there exist a moderate positive significant relationship between the prescribed contents of UBE Yoruba Language Curriculum and its implementation $(\mathrm{r}=0.464, \mathrm{P}<0.05)$. The null hypothesis is rejected. It implies that there is a significant relationship between the prescribed contents of UBE Yoruba Language Curriculum and its implementation.

\section{Hypothesis 2}

There is no significant relationship between students' attitude and acquisition of Yoruba Language skills, cultural values and the development of entrepreneurial skills.

TABLE 6

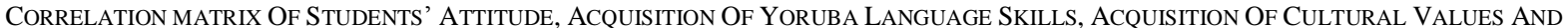
ACQUISITION AND DEVELOPMENT OF ENTREPRENEURSHIP SKILLS

\begin{tabular}{|l|l|l|l|l|}
\hline & $\begin{array}{l}\text { Students' } \\
\text { attitude }\end{array}$ & $\begin{array}{l}\text { Acquisition of } \\
\text { Yoruba language } \\
\text { skills }\end{array}$ & $\begin{array}{l}\text { Acquisition of Yoruba } \\
\text { cultural values } \\
\text { development of } \\
\text { entrepreneurship } \\
\text { skills }\end{array}$ & - \\
\hline Students' attitude & 1.000 & -.086 & - & .092 \\
\hline $\begin{array}{l}\text { Students' acquisition of Yoruba } \\
\text { Language skills }\end{array}$ & & 1.000 & $.352^{* *}$ & $.460^{* *}$ \\
\hline $\begin{array}{l}\text { Students' acquisition of cultural } \\
\text { values }\end{array}$ & & & 1.000 & $.361^{* *}$ \\
\hline $\begin{array}{l}\text { Students' acquisition and } \\
\text { development of entrepreneurship } \\
\text { skills }\end{array}$ & & & & 1.000 \\
\hline
\end{tabular}

Table 6 shows that, the relationship between students' attitude and acquisition of Yoruba Language skills ( $\mathrm{r}=-0.086$, $\mathrm{P}>0.05)$, acquisition of Yoruba cultural values $(\mathrm{r}=-.092, \mathrm{P}>0.05)$ acquisition and development of entrepreneurship skills ( $\mathrm{r}=-.024, \mathrm{P}>0.05)$ is low, negative and not significant at 0.05 level of significance. Also students' acquisition of Yoruba language skills had a low and positive relationship with students' acquisition of cultural values $(\mathrm{r}=.352, \mathrm{P}<$ 0.05 ) and students' acquisition and development of entrepreneurship skills $\mathrm{r}=.460, \mathrm{P}<0.05$ ) at level of significance in each case. Similarly, there exist a low positive and significant correlation between students' acquisition of cultural values and acquisition of entrepreneurship skills at 0.05 level of significance $r=.361, \mathrm{P}>0.05$.

\section{FINDINGS}

The findings of this study revealed that the Universal Basic Education Yoruba language curriculum booklets were not available in most schools for teachers to use. Majority of Yoruba teachers were not familiar with the curriculum and so they made use of some other available related scheme. This is in conformity with the observation of Okah (2010) that the implementation of the curriculum has been very sloppy as a result of alienation of the end users. Also Humphreys and Crawford (2014) noted that many schools lack the relevant curriculum document. Okah (2010) also noted that when many teachers were asked in a recent survey, they denied ever coming across copies of the curriculum. This indicate why teachers copied related scheme of work as yearly routine.

The result also revealed that the level of the implementation of the UBE Yoruba language curriculum was low as most of the contents were either not fully taught or not taught at all. This was in line with the view of Oforha et al (2005) that the curriculum is appropriate in terms of goals and objectives but found weak in its method of implementation. This is as a result of accumulated untaught curriculum contents in relation to the amount of teaching done.

The findings also revealed that, only few students passed the achievement test at $40 \%$ and above. The achievement 
test was to test the ability of the students and the extent of the coverage of the curriculum. The result did not meet the target of UBE Yoruba language curriculum which proposed to achieve $100 \%$ in the students' performance. This result correspond with the view of Obanya (2004) that in many cases, there would be gap between the intended curriculum and the learned curriculum. Also Ayeni (2003) opined that, the performance of learners is rated on the memory recall of the teaching contents and the success of the trained is measured in terms of overtly demonstrated skills and that, it is the skill that students are able to exhibit that shows the extent of learning. Odukoya (2010) also revealed that wide disparities in educational standard and learning achievement this is due to the process of implementation.

The findings further showed that, there is a moderate significant relationship between the prescribed contents of the Universal Basic Education Yoruba Language Curriculum and its implementation. This indicates that, so many teachers teach without following the prescribed contents, probably they teach the content at their own pace. This finding correspond with the view of Offorha (2005) that Curriculum implementation entails putting into practice the officially prescribed course of study. It is the teaching of the prescribed contents that can lead to the achievement of the stated goals. The researcher is of the opinion that where scheme of work, preparation of lesson note, statement of behavioural objective is faulty, the Curriculum implementation will also be faulty because these are the processes of the input that lead to the effective implementation of the curriculum. This also agreed with the findings of Ayodele (2008) that the knowledge of the students in the act of culture and tradition is very shallow and called for use of demonstration and videotape mediated instructional method in teaching Yoruba language and culture.

\section{Conclusion}

The UBE Yoruba Language Curriculum involved the development of human capital which can assist in the development of the nation's economy. The findings of the study revealed that the nation's educational policy to attain greatness in poverty eradication and self - reliance in order to improve the standard of living through the provision of the curriculum is a laudable programme.

However, findings of the study revealed that there is a great deficiency in the acquired learning experience and the desire learning outcome. This shows a great deficiency between the intended Curriculum and the one actually practiced by the teachers. The Curriculum itself could not go round the schools therefore many teachers were not able to lay their hands on it. The major part of the Curriculum contents were not fully taught probably this might be due to shortage of numbers of period allotted to the subject on the timetable and partly due to the little understanding and method of teaching employed by the Yoruba language teachers. In view of all these, one can conclude that the UBE Yoruba Language Curriculum has not been implemented.

\section{RECOMMENDATIONS}

Based on the findings, the following recommendations were made:

- Copies of the UBE Yoruba language curriculum should be made available to all the teachers and to the school libraries in south western Nigeria.

- Teachers should endeavour to teach the contents of the curriculum adequately and relate them to the goals and objectives of the Nigeria education.

- Since the UBE Yoruba Language Curriculum involves development and acquisition of skills, corresponding instructional materials required for learning and acquisition of Skills must be provided.

\section{REFERENCES}

[1] Adeleke, F.O (2010). Resources and materials for Teaching English Language in Nigerian primary and secondary schools in Applied Social Dimension of Language use and Teaching in West Africa: Festshrift in Honor of Tunde Ajiboye. Ghana: Ghana University Press pp. 240-244.

[2] Adeleye, M.H (2006). An appraisal of curriculum implementation in Nigeria Lagos: Macus Publication.

[3] Adeniyi, F.O (2010). Resources and materials for teaching English language in Nigerian primary and secondary schools in Applied Social Dimension of Language use and Teaching in West Africa: Festshrift in Honour of Tunde Ajiboye. Ghana: Ghana University Press pp. 240-244

[4] Ajibola, M.A. (2008). Innovation and Curriculum development for Basic Education in Nigeria: policy, priorities and challenges practice and implementation, Research Journal of International Studies. Vol. 5, issue 3 pp. 45-52

[5] Awoniyi T.A (2006). The Yoruba language and the formal school system: A study of the colonial policy in Nigeria. In journal of Educational Administration and History. Vol. 2, Issue 2, pp. 17-46

[6] Awoniyi, T.A (1978). Yoruba language in Education - Ibadan : Oxford University Press

[7] Ayeni J.O (2003): Philosophica Issues in Religion and Education; Ado - Ekiti, Greenline Publisher.

[8] Ayodele, C.A. (2008). Relative Effects of Demonstration and Video Tape Mediated Instructional Strategy on Secondary Students' performance in Yoruba Language. Unpublished M.ed Thesis UNAD.

[9] Ayodele, J.B. (2005). Fundamentals of System Analysis in Education. Ado Ekiti. Bola Bay Publishers

[10] Danmole B.T (2011) Emerging issues on the Universal Basic Education curriculum in Nigeria: Implication for the science and technology component. Pakistan Journal of Social Science Technology component 8 (1) 62 - 68.

[11] Eamon Stack (2005). An evaluation of curriculum implementation in primary schools English, Mathematics and Visual Arts Journals, Vol 5, iss. 4 pp. 54-76. 
[12] Enem F.O (2004). Vision and mission of teacher education in the $21^{\text {st }}$ century Nigeria Journal of Excellence 1 (1) 124 - 131.

[13] Fafunwa, A.B (2004). History of Education in Nigeria. Ibadan NPS Educational Publisher Ltd.

[14] Federal Government of Nigeria. (2004). Universal Basic Education (UBE) Programme. Vol 7, p. 134

[15] Humphrey, S. and Crawford, L. (2014). Issues of educational access, quality, equity and impact in Nigeria: the EDOREN review of the literature on basic education. EDOREN, Abuja.

[16] Meadar Derrick (2018). Strategies for Teachers: The power of preparation and planning. Journal for educational studies, Vol. 6, iss. 5, pp. 104-116

[17] Nigeria Education Research and Development Council (NERDC) (2008). Teachers handbook for the 9 - Year Basic Education Curriculum Junior Secondary Level. Lagos (NERDC)

[18] Obanyan, P. (2002). Revitilising Education in Africa, Ibadan Stirling Vorden publisher Nig Ltd.

[19] Obayan P. (2004). The Dilemma of Education in Africa. Ibadan. Heineman Education Books Nigeria PLC.

[20] Obiama, G. (2008). Teachers' Handbook for the 9 - year Basic Educational Curriculum NERDC.

[21] Obioma G.O. (2012). 9 year Basic Education Curriculum. Nigeria Educational Research Development Council.

[22] Odukoya, D. (2010). Teachers and materials Development. The Guardian, September 22 PP 16.

[23] Odulowu E.A. (2007). A Comparism of the Universal Basic Education programme in Nigeria and the Grundskola of Sweden UI Essay in Education 20 (1) pp 28 - 34.

[24] Ofoha D, Uchegbu C.N, Anyikwa B \& Nkemdirin. (2009). A Critical Appraisal of the Mode of Implementation of Nigerian Secondary School Curriculum: Towards Socio - economic Empowerment of Youth. Educational Research Network for West and Central Africa (ERNWACA).

[25] Ofoha Dorothy. (2011). Assessment of the Implementation of the Secondary School Skill based Curriculum to Youth Empowerment in Nigeria. Edo Journal of Counselling vol 4 los 1 \& $275-91$.

[26] Okah, I.B. (2010). Information and Communication Technology for UBE implementation in Nigeria. An imperative for achieving sustainable Millennium Development Goals. Retrieved 30/3/19 www.globalacademicgroup.com>jo.

[27] Okeke, M.I and Eme O.L. (2014). Challenges Facing Entrepreneurs in Nigeria. Singapore Journal of business economics and management studies 3 (5):18 - 34 .

[28] Oluwatayo, J.A. (2009). Primary Mathematics Curriculum: Methods and Evaluation. Ado Ekiti: Digiviews ventures Ltd.

[29] Osalusi, F.M. (2011). Developing Scientific Attitudes in Primary School Pupils: A Humanistic Approach to Social Studies Teaching and Learning. In Journal of Research in Curriculum Studies. 6(2): 46-49.

[30] Oyekan, S.O. (2015). Foundations of Teachers Education. Ondo catufey publ. Limited.

[31] Seweje, R.O. (2004). The Art of Teaching. Ado - Ekiti: Greenline Publisher.

[32] Stufflebeam, D.L. (1971). Educational Evaluation and Decision making in Education.

[33] Tyler, R.W. (1971). Basic Principles of Curriculum and Instruction: Chicago, University of Chicago Press.

[34] Umar M.A. (2006). An Evaluation of the Implementation of Junior Secondary School Studies Curriculum in Borno State, Principals Year Book.

[35] Yaaka. (2019). The concept of Education, Aims, Goals and Objectives. Unit Retrieved Feb. 5 2019. https://www.yaaka.com.

Ayodele, Christiana Ayo is a lecturer in the Department of Arts and Language Education, Ekiti State University, Ado Ekiti, Nigeria. She obtained her Ph.D. in Curriculum and Instruction. She is a member of International Reading Association. She has many publications both in local and international journals.

Oyinloye, Gabriel Oludele is a lecturer in the Department of Arts and Language Education, Ekiti State University, Ado Ekiti, Nigeria. He is a specialist in Language Education. He has many publications both in local and international journals. He is the coordinator of Literacy of Enhancement and Achievement Project (LEAP) in Nigeria. 